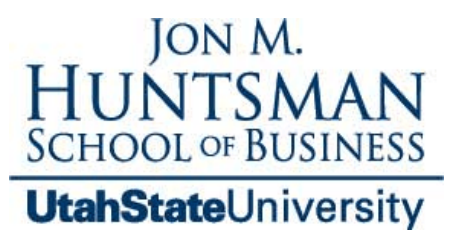

\title{
Detecting Discrimination in Small Business Lending
}

\author{
Sterling A. Bone, Utah State University \\ Glenn L. Christensen, Brigham Young University \\ Jerome D. Williams, Rutgers University \\ Stella Adams, National Community Reinvestment Coalition \\ Anneliese Lederer, National Community Reinvestment Coalition \\ Paul C. Lubin, Lubin Research
}

Copyright $(2017$ by Sterling A. Bone, Glenn L.Christensen, Jerome D. Williams, Stella Adams, Anneliese Lederer, and Paul C. Lubin.

Working papers are in draft form. This working paper is distributed for purposes of comment and discussion only. It may not be reproduced without permission of the copyright holder. Copies of working papers are available for the authors. 


\title{
Detecting Discrimination in Small Business Lending
}

\author{
STERLING A. BONE \\ GLENN L. CHRISTENSEN \\ JEROME D. WILLIAMS \\ STELLA ADAMS \\ ANNELIESE LEDERER
}

PAUL C. LUBIN*

*Sterling A. Bone (sterling.bone@usu.edu) is an Associate Professor of Marketing at Utah State University, 3555 Old Main Hill, Logan, UT, 84322. Glenn L. Christensen (g@byu.edu) is an Associate Professor of Marketing at Brigham Young University, 628 TNRB, Provo, UT, 84602. Jerome D. Williams (jeromew@business.rutgers.edu) is Distinguished Professor and Prudential Chair in Business, Provost and Executive Vice Chancellor of Rutgers University-Newark, 123 Washington Street, Suite 590, Newark, NJ, 07102-3122. Stella Adams (sadams@ncrc.org) is Chief of Equity and Inclusion, National Community Reinvestment Coalition, $74015^{\text {th }}$ Street, NW, Suite 400, Washington D.C., 20005. Anneliese Lederer (alederer@ncrc.org) is Director of Fair Lending \& Consumer Protection, National Community Reinvestment Coalition, $74015^{\text {th }}$ Street, NW, Suite 400, Washington D.C., 20005. Paul C. Lubin (plubin@lubinresearch.com), President, Lubin Research LLC, New York, NY. 


\title{
Detecting Discrimination in Small Business Lending
}

\begin{abstract}
With limited financial sophistication, entrepreneurial consumers approach the financial marketplace more like retail financial consumers than business customers. However, the assumption of both legislators and regulators is that business-borrowers are more financially savvy than consumer-borrowers, and thus do not require as broad-reaching protections. This gap between marketplace policy protections and the lived reality of the vast majority of small business entrepreneurs sets the stage for entrepreneurial consumers to fall through the regulatory cracks and sets the stage for possible exploitation and abuse. This situation is potentially exacerbated for minority entrepreneurs who belong to protected classes that are generally more vulnerable to exploitation in the marketplace including the small business lending marketplace. In this paper, we highlight the current state of this policy gap in the marketplace relative to minority entrepreneurial consumers and present a matched-paired mystery shopping study that demonstrates the critical need for reliable, primary data to inform regulatory agencies as they work to implement available protections to ensure equal access to credit within the small business lending marketplace.
\end{abstract}




\section{Detecting Discrimination in Small Business Lending}

\section{Introduction}

Customers for entrepreneurial, small-business financial products most often lack sophisticated or even basic financial acumen (Bone, Christensen, and Williams, 2014). Of the 29.6 million small businesses in the United States ${ }^{1}, 80 \%$ are sole proprietorships that have no employees at all (U.S. Small Business Administration (SBA), 2017). With limited financial sophistication, these entrepreneurial consumers approach the financial marketplace more like retail financial consumers than business customers. However, the assumption of both legislators and regulators is that business-borrowers are more financially savvy than consumer-borrowers, and thus do not require as broad-reaching protections (Wiersch and Weiss, 2015; Bone, 2006). This gap between marketplace policy protections and the lived reality of the vast majority of small business entrepreneurs sets the stage for entrepreneurial consumers to fall through the regulatory cracks which allows a greater possibility for exploitation and abuse. This situation is potentially exacerbated for minority entrepreneurs who belong to protected classes that are generally more vulnerable to exploitation in the marketplace including the entrepreneurial financial products marketplace (Bone, Christensen, and Williams, 2014).

In this paper, we highlight the current state of this policy gap in the marketplace relative to minority entrepreneurial consumers and describe what has been called "a spaghetti soup" of oversite in the current regulatory environment (Mills and McCarthy, 2016). This demonstrates the critical need for reliable, primary data to inform regulatory agencies as they work to implement available protections to ensure equal access to credit within the small business

\footnotetext{
${ }^{1}$ A small business is defined as an independent business with fewer than 500 employees (SBA, 2017)
} 
lending marketplace. To this end, we present a case study of a viable and relied upon methodology for gaining insight into small-business entrepreneurs and their experiences in the financial marketplace — matched-paired mystery shopper testing.

\section{Current State of the Regulatory Environment}

On May 10, 2017, the Consumer Financial Protection Bureau (CFPB) released a white paper and Request for Information (RFI) due September 14, 2017, regarding the Small Business Lending Market (CFPB, May 10, 2017). The Bureau is using this RFI to gain a better understanding of the small business market and the opportunities available to minority and women-owned small businesses. The Bureau is searching for greater data regarding the products offered to these businesses as well as information depicting the true costs of collecting and reporting such data (CFPB, 2017).

This is the first concrete step the CFPB has undertaken to exert its authority regarding the implementation of Section 1071. Section 1071 of the 2010 Dodd-Frank Wall Street Reform and Consumer Protection Act (Dodd-Frank) (Pub. L. 111-203, H.R. 4173) requires financial intuitions that engage in small business lending to report their lending activities with the same transparency already required of home mortgage lending sector. The CFPB has been tasked with both rule making authority and the authority to collect this data.

Since 1975, the federal government has been collecting data from financial institutions that issue home mortgages made in the United States under the Home Mortgage Disclosure Act (HMDA) (80 Fed. Reg. 66127). Under HMDA, many financial institutions are required to report their mortgage data to the public. Their reporting must include, among other data points, the race, gender, marital status, national origin, and credit score of applicants and borrowers ( 80 Fed. Reg. 66127). The federal government analyzes this data to "determin[e] whether financial 
institutions are serving the housing needs of their communities; and in identifying possible discriminatory lending patterns" (Federal Financial Institutions Examination Council, 2016). However, the home mortgage reporting requirements do not extend to small business loans. Currently, the publicly available data for small business lending has been mostly limited to the information about loans backed by the U.S. Small Business Administration (SBA), with its annual report, Small Business Lending in the United States, giving only a small peek into general small business lending practices. Community Reinvestment Act (CRA) data also offers some insight, but only shows the aggregate dollar volume of loans originated to businesses with revenues less than $\$ 1$ million and is only required from institutions with assets over $\$ 1.2$ billion. Also, there is very limited data on the experience potential applicants have during the preapplication phase and the role that discrimination could play in determining entrepreneurs' decision to apply for credit (Bone, Christensen, and Williams, 2014).

\section{Small Business Economy}

Small businesses are an integral component of America's economy. In fact, in 2013 99.9\% of all U.S. firms were small businesses (U.S. Small Business Administration (SBA), 2016), and they have provided 55\% of all jobs in the United States since the 1970s (SBA, 2017). Between 1993 and 2011, small businesses provided 63\% of net new jobs (SBA, 2016). In addition, they generated $46 \%$ of private nonfarm GDP in 2008 (Kobe, 2012). In 2012, 29.3\% of small businesses were minority-owned (SBA, 2016). Not only do these minority-owned businesses provide jobs, but they also strengthen and support communities. In the early 2000's, minority-owned businesses employed more than 4.7 million people (Silver, 2014). During the 
last two decades, minority-owned businesses have outpaced their counterparts in growth and gross receipts (Silver, 2014; Minority Business Development Agency, 2010).

Access to credit is necessary for any business to succeed. For small businesses, the inability to access credit can be particularly detrimental because it restricts these businesses from expanding. The Federal Reserve Bank’s 2016 Small Business Credit Survey highlights that 64\% of small businesses who apply for credit do so to expand business opportunities and that $55 \%$ of these applicants are looking for financing of $\$ 100,000$ or less (Federal Reserve Banks, 2017).

Both academic and private sector research reveals that minority small business owners are denied credit from traditional banking services at higher rates than white small business owners (Bates and Robb, 2015; Asiedu, Freeman, and Nti-Addae, 2012). This denial produces far greater negative results above and beyond the lack of credit availability itself for specific businesses.

The Federal Reserve Bank survey also found that $55 \%$ of small business owners surveyed did not even apply for credit (Federal Reserve Banks, 2017). The third leading reason for not applying given by the participants was discouragement, which in this study is defined as "those [firms] that did not apply for financing because they believed they would be turned down" (Federal Reserve Banks, 2017). Another Federal Reserve Bank study found that $22.2 \%$ of minority neighborhood businesses were discouraged borrowers, compared to $14.8 \%$ of businesses from other urban localities (Wiersch, Lipman, and Barkley, 2016). The probability of minority businesses owners receiving higher rates of credit denials combined with a higher likelihood of becoming discouraged borrowers yields negative repercussions for minority communities. 
This disproportionate credit denial creates a perception among minority small business owners that there is no credit available to them from traditional sources; as these business owners still need loans, they turn to alternative sources of financing (Wiersch, Lipman, and Barkley, 2016). Alternative sources of credit on their face may sound like viable solutions but some borrowers may inadvertently succumb to predatory lenders (Weinberger, 2017; CFPB, 2016).

In essence, the actual denial of a business owner's application for credit is not the only stage of the process when credit is denied. Denial of credit also occurs when the applicant consciously chooses not to submit an application at all, whether due to prior negative experiences and interactions with banks or due to the applicant's general impression that the application will be denied (Federal Reserve Banks, 2017; Bates and Robb, 2015; Bone, Christensen and Williams, 2014). The Kauffman Foundation highlighted this negative disproportionate reality reporting that " $58.5 \%$ of [African American] entrepreneurs who did not seek additional financing despite needing it [did so] because they thought the business would not be approved by a lender... [and] are almost three times more likely than whites to have profits negatively impacted by lack of access to capital" (Ewing Marion Kauffman Foundation, 2016).

\section{State of the Law and Regulation of Small Business}

Congress enacted the Equal Credit Opportunity Act (ECOA) in 1974. In 2010, under

Dodd-Frank, jurisdiction for ECOA was largely transferred from the Board of Governors of the Federal Reserve System (the Federal Reserve Board) to the newly created CFPB. As a result, Dodd-Frank effectively gave the CFPB rule making, supervisory, and enforcement powers regarding ECOA for most financial institutions. ${ }^{2}$

\footnotetext{
2 The CFPB regulates ECOA compliance for banks, savings associations, and credit unions with assets over $\$ 10$ billion. It shares enforcement authority with the Federal Trade Commission over mortgage brokers, mortgage
} 
ECOA is one of a few laws that provide fair lending protections for consumers. The Fair Housing Act also extends fair lending protections to consumers (42 U.S.C. $§ 3605$ ). However, the Fair Housing Act's jurisdiction is limited to financial creditors who engage in residential real estate related transactions, commonly referred to as mortgage products. ECOA expands fair lending laws to all creditors; "it is not limited to consumer loans. [ECOA is] applied to any extension of credit, including extensions of credit to small business." (The Department of Housing and Urban Development (HUD) et al., 1994).

There are eight protected classes under ECOA: race or color, religion, national origin, sex, marital status, age (provided the applicant has the capacity to contract), the applicant's receipt of income derived from any public assistance program, and the applicant's exercise, in good faith, of any right under the Consumer Credit Protection Act (59 Fed. Reg. 73, 1994).

Under ECOA a creditor is prohibited from discriminating against a member of a protected class at any time during the credit transaction, including activities occurring in the preapplication phase (59 Fed. Reg. 73, 1994). Discriminatory actions include but are not limited to:

- Failing to provide information or services or provide different information or services regarding any aspect of the lending process, including credit availability, application procedures, or lending standards;

- Discouraging or selectively encouraging applicants with respect to inquiries about or applications for credit;

\footnotetext{
originators, mortgage servicers, lenders offering private education loans, and payday lenders, regardless of size. The Comptroller of Currency has compliance authority for national banks, federal savings associations, and federal branches of foreign banks with total assets under $\$ 10$ billion. The Federal Reserve Board retains compliance authority for financial institutions with total assets under $\$ 10$ billion that are members of the Federal Reserve System. The Federal Deposit Insurance Corporation has compliance authority over state banks with total assets under $\$ 10$ billion. The National Credit Union Association has compliance authority over federal credit unions (United States Department of Justice (2016).
} 
- Refusing to extend credit or use different standards in determining whether to extend credit;

- Varying the terms of credit offered, including the amount, interest rate, duration, or type of loan;

- Using different standards to evaluate collateral (59 Fed. Reg. 73, 1994).

It is the role of federal agencies to enact and enforce the laws that Congress passes. Within a single law, oversight and enforcement responsibilities may fall on a single agency or be shared among many different agencies. There are at least six different agencies that have regulatory authority over financial institutions that issue small business loans, in addition to individual state regulations and oversight (Mills and McCarthy, 2017). This fragmented and sometimes overlapping approach can make effective oversight challenging and risks leaving gaps in important protections for small-business entrepreneurs. Until the implementation of Section 1071 of the Dodd Frank Act, most of the regulations in place to protect borrowers specifically related to consumer loans, not small business loans (Mills and McCarthy, 2017). As previously noted, it is the apparent assumption of both legislators and regulators is that businessborrowers are more financially savvy than consumer borrowers, and thus do not require as broad-reaching protections (Wiersch and Weiss, 2015; Bone, 2006). However, unlike commercial borrowers who often have staff with financial expertise and long-term banking relationships, many small business owners have limited exposure to traditional credit and banking procedures. The current gaps in regulation and oversight, particularly in the online lending space, has left the small business-lending environment open for potential abuse. The implementation of Section 1071 is the first step to better understanding the small business- 
lending marketplace and offering transparency into the types of products and terms small business borrowers are entering into.

\section{Small Business Lending Data}

The SBA produces an annual report entitled Small Business Lending in the United States (U.S. Small Business Administration, 2013). The report examines "depository lending institutions and their lending patterns to small businesses" (U.S. Small Business Administration, $2013,1)$. However, the report is limited to data obtained from the only two publically available sources of information on small business lending: Call Reports (data collected by the Federal Deposit Insurance Corporation) and CRA data (collected by Federal Financial Institutions Examination Council). These two data sources only reflect the supply of loans, meaning loans that were actually provided by banks and savings and loans associations. They do not reflect demand, meaning those loans applied for but never obtained, nor do they reflect other sources of marketplace credit such as suppliers, credit cards, families and friends, or finance companies (U.S. Small Business Administration, 2013).

Beyond the SBA's annual report, other sources of small business data are extremely limited. Lenders are required to report small business lending data regarding the administration of SBA 7(a) Program loans (Office of the Comptroller of the Currency (OCC), 2014). However, in FY2015, only 2,163 lenders participated in the SBA 7(a) lending program, which was the lowest number of participants in 8 years, and most lenders originate fewer than 107 (a) loans per year (OCC, 2014). Like the Call Reports and CRA data referenced above, this data only reflects loans that are approved by the bank, not applications that are denied. Upon request to the SBA, 
the public can obtain race and gender data on the SBA programs' small business borrowers, but it is not regularly published (Silver, 2014).

The Community Development Financial Institutions (CDFI) Fund will also provide loan data by request, but this data only shows the county where funds are distributed and the purpose and use of the funds (Silver, 2014). Several private and nonprofit entities, like the Ewing Marion Kauffman Foundation, Graziadio School of Business and Management,and the FIELD Program at the Aspen Institute have attempted various forms of surveys across a multitude of small business owner populations, but each of these surveys only provide fragmented subsets of information and lack common variables which would enable comprehensive comparisons and conclusions (Silver 2014).

The CFPB, using the limited data available, estimates that the small business financing market is approximately $\$ 1.4$ trillion, with only $7 \%$ of those loans being SBA Program loans (CFPB, 2017). This means, due to the lack of required reporting, there is over $\$ 1.3$ trillion in financing issued by banks, non-banks, online lenders, and other marketplace financers for which is there no publically data on terms, conditions, or demographics of the products and consumers, and no data-driven understanding of the marketplace in which these loans were issued.

Data is a required component in combatting institutional and systematic discrimination, but it is not effective in a vacuum. Matched-pair mystery shopper testing is a valuable investigative tool (Freiberg, 2009) for uncovering the systematic and institutional barriers that raw data and surveys alone cannot detect. The U.S. Department of Justice, the CFPB, and HUD have all used mystery shopping testers to uncover institutional discrimination that exists in consumer lending. However, to date, none of these agencies have attempted to use mystery 
shopping testing to uncover potential discrimination possibly faced by minority small business entrepreneurial consumers.

The implementation of HMDA led to a rise in the targeting and efficiency of mystery shopping testing and, in turn, an increase in enforcement of the fair lending laws in retail consumer credit (Ahuja, 2017). We propose that the proper implementation of Section 1071 may have a similar effect and could spur financial institutions to working harder on comprehensive, nondiscriminatory approaches to all types of lending including lending to entrepreneurial small business consumers.

We will now present a case study to demonstrate how a matched-pair mystery shopping methodology can be used to investigate potential differences in lending treatment to minority small business consumers. This case study illustrates the nuanced ways that minorities may be disproportionally denied credit or become discouraged borrowers and highlights the need for the implementation of regulations like Section 1071 to shine more light on these disparities.

\section{Small Business Lending Mystery Shopping Case Study}

Method

We conducted fair lending tests using a matched-paired mystery shopping methodology to test for racial discrimination in small business lending. The purpose of this mystery shopping research, commonly known as "testing", was to determine the baseline customer experience level that minority and non-minority mystery shoppers received when seeking information about small business loans. We investigated the potential for disparate treatment of small business customers during the preapplication (or loan inquiry) stage of the loan application process at a bank. Mystery shopping audit studies have been conducted in a variety of service sectors (Finn 2007) 
to detect discrimination, such as in the case of car shopping (Ayres and Siegelman 1995) and renting an apartment or purchasing a home (Galster 1991; Yinger 1998). Mystery shopping methods are ideal to capture factual evidence beyond potentially subjective perceptions of the experience (Ainscough and Motley 2000; Finn 2001). Precedent exists for using mystery shopping in discrimination litigation in the United States that assess employee and firm performance to determine whether consumers receive differential treatment in the "process" of requesting products/services (Lubin 2011). Financial institutions regularly conduct "testing" mystery shopping studies in response to and in prevention of fair-lending violations (Lubin 2011). For example, banking institutions regularly conduct mystery shopping tests to mitigate and eliminate the risks and penalties resulting from routine regulatory and compliance fair lending audits.

\section{Bank Sampling}

We tested 16 bank locations in two large metropolitan statistical areas (MSAs) in the eastern United States. These markets were selected by first analyzing the regional demographic composition of each bank's location according to the United States' 2010 Census Data tracts categorized as low, moderate, middle, and upper income as classified under Consumer Reinvestment Act (CRA) guidelines using median family income. We then used CRA data collected by the Federal Financial Institutions Examinations Council (FFIEC) to determine the lending patterns of these banks. This data revealed the number and dollar amount of loans originated to each census tract. This study analyzes interactions amongst branches that have high, moderate, and low levels of spending to those of low-moderate income tracts. We 
conducted a total of 52 tests (or 26 matched-pairs with one African-American tester and one Caucasian tester).

Study Design and Procedures

We recruited six African American and five Caucasian male testers to test for the protected group of race under ECOA. African American testers were the protected group and the Caucasian testers served as the control group. Testers were trained extensively about business and banking terminology and loan products. The testers were matched and pretested on critical personal characteristics (e.g., age, height, body build, attractiveness, education) (Ainscough and Motley 2000; Lubin 2011). All testers wore a blue collared shirt and khaki trousers. Matching testers on these personal characteristics enabled us to compare the outcomes of the tests by race.

Testers came to the banks with nearly identical business profiles and strong credit histories to inquire about a small business loan product $(\$ 60,000-\$ 70,000$ loan to expand their business and to possibly hire a part-time employee). The profiles of the test and control groups were sufficiently strong that on paper, either profile would be very likely to be approved for a loan. We slightly modified the distinguishing characteristics of borrower characteristics, including the consumer's name, the company name, and reason for visiting this bank. We did this to reduce the chance that testers would be detected as mystery shoppers. We designed the profiles for both the protected and control testers to be well above the threshold of what is acceptable loan requests, however, we designed the qualifications of African American testers to be superior to the qualifications of the Caucasian testers. In other words, on paper the protected, African American, tester was financially better off than the control, Caucasian, tester. Thus, one would hope for the experience of African Americans to be more positive, or at the very least, 
equal to the experience of the Caucasians. This makes this study a conservative test for the presence, if any, of disparate and discriminatory treatment in the test condition.

Each pair of testers was assigned to visit the same retail location of the bank; one visited in the morning and the other in the afternoon. We alternated the times of the assignments within the race/test variable. Testers were trained to conduct each test and shown how to capture and record the pertinent information needed to complete an online questionnaire immediately after each visit using iPads and an online survey instrument. Once the test was completed, the test coordinator followed up with each tester to review their testing experience.

On entering the bank, the tester stated that he was interested in meeting with someone about a loan for his small business. In most cases, the testers were directed to a bank loan officer from whom they gathered information on available loan and financial products. Consistent with the preapplication tests used by regulatory agencies and the courts (Lubin 2011), testers listened and gathered the information provided about the options, availability, and terms of the financial products discussed.

The questionnaire measured three classes of the consumers' experience with bank officers, including the information provided, the information required for loan application, and the encouragement and assistance demonstrated to the consumer (Bone, Christensen, and Williams 2014). We selected the measures on the basis of their accepted and relied upon status in legal precedent and regulatory usage (Lubin 2011).

Results

We analyzed the data using the chi-square difference test on the proportions of reported values for African American and Caucasian testers. We compared differences in the information 
requested by the bank officer. The results show that African-American testers were asked to provide more information about their businesses and personal financials than Caucasian testers. Specifically, compared with the Caucasian testers, African American testers were more frequently requested to provide the information of their business financial statements $(73.1 \%$ vs. $\left.50.0 ; \chi^{2}=2.93 ; p=.09\right)$, the amount of their accounts receivable $\left(11.5 \%\right.$ vs. $0.0 \% ; \chi^{2}=3.18 ; p=$ $.07)$, and their personal W-2 forms $\left(30.8 \%\right.$ vs. $\left.0.0 \% ; \chi^{2}=9.46 ; p=.01\right)$. In addition, we identified a troublesome pattern of loan officers inquiring about marital status. Asking about marital status as a determination of credit worthiness is a direct violation of fair lending law (15 USCS $\S 1691$ ). We found that African American testers were asked if they were married (marital status) $(\mathrm{M}=23.1 \%)$ significantly more frequently than compared to Caucasian testers $(\mathrm{M}=$ $\left.3.8 \% ; \chi^{2}=4.13 ; p=.04\right)$. In addition, African American testers were asked about spousal employment status $(\mathrm{M}=11.5 \%)$ significantly more frequently than compared to Caucasian testers $\left(\mathrm{M}=0.0 \% ; \chi^{2}=3.18 ; p=.07\right)$. The similar test and control profiles are created in a manner that should result in a loan approval based solely on the income of the tester alone. There would be no reason or need to incorporate a spouse's income into the credit worthiness decision-making process. Furthermore, only the Africa-American testers where asked if their spouse is employed.

The results also reveal differences in the level of assistance and encouragement offered to the African American testers. Compared with their Caucasian counterparts, African American testers were less frequently thanked for coming in $\left(80.8 \%\right.$ vs. $\left.96.2 \% ; \chi^{2}=3.01 ; p=.08\right)$. Micro-aggressions. In addition to analyzing the data using empirical quantitative methods, we collected detailed narratives from each test. In these narratives the tester was asked to explain each of the actors (e.g. bank employees) involved, the detailed events of their 
interaction and the conversation and discourse they experienced during their time in the bank. Comparing the narratives of the African-American testers to the Caucasian narratives revealed that African-American testers experienced micro-aggressions along with the disparate treatment they received. Victims of consumer discrimination bear a psychological burden as a result of overt and subconscious discrimination. Because consumer discrimination occurs in everyday situations, it constitutes the kind of micro-aggressions that can have cumulative debilitating effects over the course of a person's lifetime (Sue et al. 2007). For example, we found that on multiple occasions the loan officer during their visit with African American testers went to a government website listing all registered businesses to verify if the minority tester's business was registered and in good standing. This did not occur for any Caucasian tester.

Analyzing the narratives of matched-paired tests to the same bank location revealed other types of micro-aggressions experienced and reported by African-American testers. For example, while both testers lived about an hour from the bank branch, it was suggested to the AfricanAmerican tester to visit a bank branch closer to his home, while the Caucasian tester was told that the business specialist is not in and offered to set up a meeting for the next time the business specialist is available. Another example that occurred is of a matched-pair where the tester met with the same loan officer on the same day. Both testers were asked about the location of their business which was according to the scenario they were trained on, about an hour away from the bank. In this incident, the African-American tester was then asked why he was in area and he responded as directed by saying that he was in the area to meet with a potential client. On the other hand, the Caucasian tester was not asked this question. 
The analysis of narratives also revealed product steering by the bank officers who mentioned and explained home equity loans of credit (HELOC) to African American testers, but did not do so with the Caucasian testers they met with on the same day.

\section{Conclusion}

A careful review of the current state of public policy, regulation, small business economy and the limited availability of data on small business lending reveal a research and societal imperative to implement systematic data collection around small business lending practices. At this juncture where new policy is being created around the implementation of Section 1071, reliable and accepted methods to supply useful data to policymakers is both timely and important. One approach of how this might be done is illustrated in the matched-paired mystery shopping case study, where the purpose was to determine the presence, if any, of disparate and discriminatory treatment in the test condition. Our findings suggest that public policy makers, including the CFPB need to engage in a dialogue with the financial industry, regulators and public at-large to discuss the social and economic imperatives of protecting small business entrepreneurial consumers. This will be accomplished as the CFPB works with financial industry leaders to develop "best practices" and other compliance measures to ensure that all potential applicants receive information in in the same manner on a level playing field. Data collection efforts should concentrate on gathering data to ensure that:

1. Loan information provided by loan officers does not vary, regardless of the consumer's race/ethnicity;

2. Bank officers impose a similar standard of scrutiny to all borrowers applying for a loan; and 
3. Bank officers provide appropriate encouragement and assistance to all potential loan applicants regardless of race/color.

In the presented case study, the tests were designed to present the African American tester as the most creditworthy. Despite this fact, on several measures the matched-paired mystery shopping study revealed that the African American testers underwent a higher level of scrutiny and received a lower level of assistance than their less-creditworthy Caucasian counterparts. Also, African American testers were asked significantly more often about their marital status and their spouse's employment, which marks another and even illegal differential experience for these minority entrepreneurial consumers compared with the Caucasian shoppers.

Preapplication testing should be utilized to enforce existing fair lending laws. Under ECOA a creditor is prohibited from discriminating against a member of a protected class at any time during the credit transaction including activities occurring in the pre-application phase (59 Fed. Reg. 73, 1994). Results from our study indicate that matched-paired mystery shopping testing for enforcement purposes would reveal evidence that bank officers may sometimes provide different information or services regarding credit availability, application procedures, and lending standards; discouraging minority applicants with respect to inquiries about or applications for small business credit; and use different (even potentially illegal) standards in determining whether to extend credit (59 Fed. Reg. 73, 1994). 


\section{References}

Ahuja, Vedika (2017), "Small Business Loans Need Their Own HMDA," American Banker, Accessed August 22, 2017, https://www.americanbanker.com/opinion/small-business-loansneed-their-own-hmda.

Ainscough, Thomas and Carol M. Motley (2000), "Will You Help Me, Please? The Effects of Race, Gender and Manner of Dress on Retail Service," Marketing Letters, 11 (May), $129-35$.

Asiedu, Elizabeth, James A. Freeman, and Akwasi Nti-Addae (2012), “Access to Credit by Small Businesses: How Relevant Are Race, Ethnicity, and Gender?” American Economic Review, 102(3), 532-537.

Ayres, Ian and Peter Siegelman (1995), "Race and Gender Discrimination in Bargaining for a New Car, “American Economic Review, 85 (June), 304-21.

Bates, Timothy and Alicia Robb (2015), "Impacts of Owner Race and Geographic Context on Access to Small-Business Financing, Economic Development Quarterly (Vol. 30(2)), 159170.

Bone, Sterling A. (2006), “To Accept or Reject a Customer's Business? The Interaction of Customer Quantitative Merit, Customer Reputation and the Decision-Maker's Need for Discretion," Oklahoma State University, ProQuest Dissertations Publishing.

— Glenn L. Christensen, and Jerome D. Williams (2014), "Rejected, Shackled, and Alone: The Impact of Systemic Restricted Consumer Choice on Minority Consumers' Construction of Self," Journal of Consumer Research, 41 (2): 451-474.

Consumer Credit Protection, Equal Credit Opportunity, Scope of Prohibition, 15 USCS § 1691. 
Consumer Financial Protection Bureau (CFPB) (2017), “CFPB Explores Ways to Assess the Availability of Credit for Small Business, May 10, 2017, Accessed June 23, 2017, https://www.consumerfinance.gov/about-us/newsroom/cfpb-explores-ways-assessavailability-credit-small-business/.

Consumer Financial Protection Bureau (CFPB) (2017), "Request for Information Regarding the Small Business Lending Market,” Accessed June 23, 2017, https://www.consumerfinance.gov/policy-compliance/notice-opportunities-comment/opennotices/request-information-regarding-small-business-lending-market/.

Consumer Financial Protection Bureau (CFPB) (2016), "Payday Loans, Auto Title Loans, and High-Cost Installment Loans: Highlights from CFPB Research, (Summary of CFPB Research)," Accessed July 10, 2017, http://bit.ly/2dnHLn4.

Dodd-Frank Wall Street Reform and Consumer Protection Act (2010), Pub. L. 111-203, H.R. 4173.

Ewing Marion Kauffman Foundation. Startup Financing Trends by Race: How Access to Capital Impacts Profitability (2016), October 24, 2016, Accessed July 10, 2017, http://www.kauffman.org/what-we-do/research/2016/startup-financing-trends-by-race-howaccess-to-capital-impacts-profitability.

Federal Financial Institutions Examination Council (FFIEC) (2016), "Background and Purpose," (September 29, 2016). Accessed July 10, 2017, https://www.ffiec.gov/hmda/history.htm. Federal Reserve Banks, "Small Business Credit Survey: Report on Employer Firms,” (2017, April), Accessed July 10, 2017, http://nyfed.org/2obZUFM.

Finn, Adam (2001), "Mystery Shopper Benchmarking of Durable-Goods Chains and Stores," Journal of Service Research, 3 (4), 310-20. 
— (2007), "Doing a Double Take: Accounting for Occasions in Service Performance Assessment," Journal of Service Research, 9 (4), 372-87.

Freiberg, Fred (2009), “A test of our fairness,” The Urban Lawyer, 41 (2), Spring, 239-248.

Galster, George C. (1991), "Housing Discrimination and Urban Poverty of African-Americans," Journal of Housing Research, 2 (2), 87-122.

Home Mortgage Disclosure (Regulation C), 80 Fed. Reg.66127 (updated 11/10/15), Accessed July 10, 2017, https://www.federalregister.gov/documents/2015/10/28/2015-26607/home$\underline{\text { mortgage-disclosure-regulation-c }}$

Kobe, Kathryn (2012), “Small Business GDP: Update 2002-2010,” (January), Accessed June 23, 2017, https://www.sba.gov/content/small-business-gdp-update-2002-2010.

Lubin, Paul C. (2011), Protecting Main Street: Measuring the Customer Experience in Financial Services for Business and Public Policy, New York: Routledge.

Mills, Karen Gordon and Brayden McCarthy (2016), "The State of Small Business Lending: Innovation and Technology and Implications for Regulation" Harvard Business School, http://hbs.me/2gIAKfx.

Minority Business Development Agency (MBDA) (2010), "Disparities in Capital Access between Minority and Non-Minority Owned Businesses: The Troubling Reality of Capital Limitations Faced by MBEs,”(January), Accessed July 10, 2017, https://www.mbda.gov/sites/mbda.gov/files/migrated/filesattachments/DisparitiesinCapitalAccessReport.pdf.

Office of the Comptroller of the Currency (2014), "Insights," (December), Accessed August 3, 2017, https://www.occ.gov/topics/community-affairs/publications/insights/insights-bankersguide-sba7a-loan-program.pdf. 
Silver, Josh (2014), Small Business Loan Data: Recommendations to the Consumer Financial Protection Bureau for Implementing Section 1071 of the Dodd-Frank Wall Street Reform and Consumer Protection Act of 2010, National Community Reinvestment Coalition White Paper, 13, Accessed July 10, 2017, http://bit.ly/2tTTQWW.

The Department of Housing and Urban Development (HUD), the Office of Federal Housing Enterprise Oversight (OFHEO), the Department of Justice (DOJ), the Office of the Comptroller of the Currency (OCC), the Office of Thrift Supervision (OTS), the Board of Governors of the Federal Reserve System (Board); Federal Deposit Insurance Corporation (FDIC); Federal Housing Finance Board (FHFB), the Federal Trade Commission (FTC), and the National Credit Union Administration (NCUA) (1994), Policy Statement on Discrimination in Lending, 59 Fed. Reg. 73 (April 15, 1994).

The Federal Reserve Board. (2008), "Survey of Small Business Finances,” (October 15), Accessed June 26, 2017, https://www.federalreserve.gov/pubs/oss/oss3/nssbftoc.htm

U.S. Small Business Administration (2013), "Small Business Lending in the United States 2012," (July), Accessed August 3, 2017, https://www.sba.gov/sites/default/files/files/sbl 12study.pdf.

U.S. Small Business Administration (2016), "Frequently Asked Questions," (June), Accessed June 23, 2017, https://www.sba.gov/sites/default/files/advocacy/SB-FAQ-2016 WEB.pdf.

U.S. Small Business Administration (2017), "Small Business Trends," Accessed June 23, 2017, https://www.sba.gov/managing-business/running-business/energy-efficiency/sustainablebusiness-practices/small-business-trends.

Weinberger, Evan (2017), "House Dem Wants Info on Fintech Small-biz Lending," Law360 (June 2017), Accessed July 10, 2017, http://bit.ly/2uZQNwr. 
Wiersch, Ann M. and Christine Weiss (2015), "Protecting Small-Business Borrowers," Forefront: New Ideas on Economic Policy from the Federal Reserve Bank of Cleveland, Accessed August 5, 2017, https://www.clevelandfed.org/newsroom-andevents/publications/forefront/ff-v6n03/ff-20151207-v6n03-protecting-small-businessborrowers.aspx.

—_, Barbara J. Lipman, and Brett Barkley (2016), “Click, Submit: New Insights on Online Lender Applicants from the Small Business Credit Survey," Click, Submit: New Insights on Online Lender Applicants from the Small Business Credit Survey, Accessed July 11, 2017, http://bit.ly/2sYZju2.

Yinger, John (1998), "Evidence on Discrimination in Consumer Markets," Journal of Economic Perspectives, 12 (2), 23-40. 